\title{
STRATEGI KOMUNIKASI POLITIK TOKOH PURI UBUD DALAM MEMPERTAHANKAN EKSISTENSI DAN TRADISI BALI
}

\author{
I Wayan Suartawan, Redi Panuju \\ Program Studi Ilmu Komunikasi \\ Universitas Dr Soetomo \\ Email : suartawanbali@gmail.com, redi.panuju@unitomo.ac.id
}

\begin{abstract}
ABSTRAK
Mempertahankan tradisi di era modern merupakan tantangan, tidak terlepas juga bagi masyarakat Ubud, Kabupaten Gianyar, Propinsi Bali. Desa ini dikenal sebagai destinasi wisata terbaik dunia. Efeknya, interaksi antara pendatang dan wisatawan dengan masyarakat setempat berpotensi merubah tatanan tradisi. Kemajuan pariwisata semakin menguatkan terjadinya perubahan. Namun, pada kenyataannya tradisi di Ubud tidak sepenuhnya berubah, bahkan beberapanya semakin berkembang. Jauh sebelum pesatnya pariwisata, pelestarian dan penanaman tradisi sudah dilakukan masyarakat Ubud, dipimpin Puri Ubud yang saat itu menjadi Raja Ubud. Tatanan pemerintahan dan kekuasaan melanggengkan tradisi, begitupun sebaliknya. Wisatawan yang datang ke Ubud umumnya ingin menyaksikan tradisi dan budaya masyarakat Ubud, sehingga akhirnya antara tradisi dan pariwisata menjadi saling ketergantungan. Perubahan tata pemerintahan pasca kemerdekaan hingga orda baru membuat kewenangan Puri Ubud terbatas, tokoh Puri Ubud mulai berbenah agar tradisi tidak hancur. Kesempatan mengembalikan era kekuasaan zaman dahulu terbuka lebar pasca reformasi, tokoh Puri Ubud masuk dalam organisasi tradisional, sosial hingga politik. Francis Fukuyama menyebut hal itu sebagai modal sosial berupa jaringan sosial. Sosiolog Prancis Pierre Bourdieu (2010) menyebut symbolic capital,. Lebih lanjut menurut Bourdieu ada empat modal yang bisa dipergunanakan dalam mendukung komunikasi politik, yakni modal kapital, modal ekonimi, modal budaya dan modal simbolik. Penelitian ini menggunakan teknik kualitatif deskriptif, pengumpulan data berupa wawancara, observasi, studi dokumen. Ada dua teori yang digunakan yaitu, Teori Praktik dan Teori Komunikasi Massa. Penelitian ini mengungkap bentuk atau metode komunikasi politik Puri Ubud dalam mempertahankan tradisi. Tujuan penelitian ini berkaitan dengan upaya penulis dalam mempertahankan tradisi dan kekuasaan Puri Ubud di zaman modern.
\end{abstract}

Kata kunci: tradisi, komunikasi, puri ubud.

\section{A. PENDAHULUAN}

Mempertahankan tradisi di era modern menjadi tantangan komponen bangsa, tradisi tersebut merupakan jiwa suatu bangsa yang bernilai tak terhingga. Di Bali, tradisi merupakan warisan bernilai yang tidak terukur. Bali tanpa tradisi tidak akan mampu mempertahankan eksistensinya di berbagai aspek sosial dan budaya. Tradisi bisa disebut sebagai nafasnya Bali. Sejak Nusantara menjadi Republik Indonesia, telah terjadi perubahan dalam aspek tatanan sosial masyarakat Bali, termasuk juga di Desa Ubud, Kabupaten Gianyar, Bali.
Bali kuno sebelum Kemerdekaan Republik Indonesia, pola pemerintahannya masih menggunakan sistem kerajaan. Namun setelah kemerdekaan, Bali menjadi republik dan pemimpin dipilih secara demokrasi. Meski demikian perubahan sistem pemerintahan maupun kepemimpinan tidak menghapus nilai lama yang menjadi jiwa dalam kehidupan masyarakat Bali, termasuk di Ubud. Hal tersebut tak lepas dari peran puri atau keraton bekas kerajaan terdahulu.

Puri Ubud di Kecamatan Ubud Kabupaten Gianyar merupakan salah satu 
puri yang masih memegang nilai tradisi. Puri Ubud bahkan dijadikan barometer pelestarian tradisi di Bali. Hingga kini Puri Ubud masih mempertahankan tradisi leluhur yang adiluhung, termasuk nilai kepemimpinannya. Hal tersebut dapat dibuktikan dari pelbagai ritual, bangunan, kegiatan sosial serta berbagai aspek kehidupan masyarakat Ubud. Termasuk juga sistem demokrasi yang masih berpedoman pada tradisi yang dipegang kalangan Puri Ubud. Kehidupan demokrasi yang dijalankan pada era republik sekarang sebagian besar bersumber dari budaya dan tradisi yang melandasi kehidupan masyarakat Bali. Praktek serupa juga bisa dijumpai pada hampir semua etnis dan suku bangsa, karena merupakan demokrasi asli masyarakat lokal pada berbagai daerah di Indonesia, Alfian (1991:134-135).

Walaupun berbeda dengan pola kepemimpinan Negara Indonesia, tradisi kerajaan tersebut mampu membawa Ubud menjadi salah satu tujuan pariwisata terbaik dunia. Tradisi Ubud mampu menyedot jutaan wisatawan untuk datang ke Ubud. Namun tanpa disadari, pariwisata sangat berpengaruh terhadap tatanan masyarakat Ubud. Pengaruh globalisasi serta kemajuan teknologi membuat tradisi semakin dilupakan.

Peran puri termasuk tokoh puri dalam mempertahankan tradisi dilaksanakan lewat berbagai kegiatan dan media, seperti, kegiatan keagamaan, sosial, ekonomi hingga politik. Tradisi merupakan bagian dari budaya yang merupakan hasil karya manusia dan disepakati umum, namun dalam globalisasi kesepakatan tersebut selalu dinamis sesuai pengaruh budaya lain. Pesatnya perkembangan pariwisata secara pelan merubah tatanan tradisi. Budaya Bali khususnya di kawasan wisata Ubud juga mulai berubah. Padahal, Ubud merupakan salah satu desa yang dikenal hingga mancanegara akan kuatnya budaya dan tradisi.

Pelestarian tradisi tersebut tak lepas dari peran tokoh Puri Ubud yang konsen mempertahankan tatanan budaya. Sejak dikenalkan ke dunia luar sekitar tahun 1930, salah satu tokoh Puri Ubud kala itu, Tjokorda Gede Agung Sukawati yang dinobatkan menjadi Raja Ubud sempat melanglang Eropa. Tokoh ini membuka pintu istananya untuk ditempati orang asing dan menjadi cikal bakal pariwisata di Ubud. Padahal, kala itu puri di Bali masih selektif menerima tamu asing, akses hanya dibuka untuk warga yang menjadi abdi atau rakyat puri dengan tata krama tersendiri. Kebijakan itu fenomenal, sehingga banyak warga di sekitarnya juga membuka akses bagi pelancong dan menjadi cikal bakal Home Stay di Ubud.

Dua orang pelancong yang mengenalkan Ubud ke mata dunia yakni, Walter Spies dan Rudofl Bonnet. Lewat lukisan, dua seniman tersebut mengenalkan Ubud ke mancanegara, bahkan Bonnet saat wafat, mayatnya dibakar sesuai tradisi Bali bersama Tjokorda Gede Agung Sukawati. Pesatnya pariwisata serta pola pemerintahan dan praktek budaya demokrasi itu mengikuti proses sosial dan budaya yang membawa orang Bali dalam posisi transisional. Salah satu parameternya adalah peralihan dari budaya Bali klasik yang otoriter dan feodalistik menjadi budaya Bali yang modern, demokratis dan egalitarian, Naya Sujana (1994:56).

Peralihan budaya serta berbagai pristiwa tersebut menjadi salah satu pemicu pesatnya perkembangan pariwisata di Ubud. Bahkan, Presiden Amerika Jhon F. Kenendy tahun 1967 sempat bersambang ke Puri Ubud dan melihat beberapa karya seniman Ubud dan karya Walter Spies di Museum Puri Lukisan Ubud. Sejak itu, pariwisata di Ubud semakin tidak terbendung. Disamping menimbulkan dampak positif, dampak negatif juga menyertainya. Wisatawan di Ubud secara tidak sadar telah mengubah tradisi tersebut secara perlahan.

Menyadari hal itu pihak Puri Ubud berupaya mempertahankan tradisi lewat pelbagai lini. Misalnya dengan melaksanakan berbagai upacara, ritual, kesenian, pameran, meningkatkan modal sosial, ekonomi, hingga pementasan tari dan lainnya. Tokoh puri mulai menggali 
potensi demi lestarinya tradisi. Hanya saja, pelestarian lambat laun akan tidak efektif tanpa disertai modal. Beberapa puri di Bali juga melaksanakan hal serupa, namun akibat berbagai kendala, terutama modal, tradisi memudar. Disamping kebutuhan ekonomi, niat mengabdi pada tradisi sudah mulai menipis. Berbeda dengan dulu, ekonomi bukan menjadi tujuan utama. Tradisi masih bisa dijaga dengan pengabdian, disamping rasa takut terhadap hukum raja. Mengantisipasi itu beberapa tokoh Puri Ubud mulai masuk dalam aktivitas sosial, menjadi pimpinan organisasi sosial, mendirikan sanggar kesenian, anggota dewan hingga menjadi pimpinan daerah. Berangkat dari itulah, artikel ini akan meneiti lebih jauh mengenai strategi komunikasi politik apa saja yang digunakan oleh para tokoh Puri Ubud dalam mempertahankan tradisi (politik) di Bali.

\section{B. METODE}

Penelitian ini menggunakan pendekatan kualitatif dengan penelitian lapangan (field research). Data diperoleh melalui wawancara mendalam kepada informan dari kalangan Puri Ubud yang aktif dalam kegiatan politik praktis. Untuk kepentingan analisis dikaitkan dengan data skunder berupa informasi dari media.

\section{LANDASAN TEORI}

Dalam penelitian ini peneliti akan menggunakan beberapa teori, pertama, hypodermic needle theory yaitu pesan yang disampaikan langsung mengenai sasaran. Kedua, user and gratifications theory, yakni, teori yang berkaitan dengan sikap dan prilaku konsumen. Ketiga, teori kebutuhan, manusia memiliki tingkatan kebutuhan psikologis, kasih sayang, rasa aman, penghargaan dan aktualilasi diri yang harus dipenuhi. Keempat, cultivation theory yakni menggambarkan kehebatan televisi menanamkan sesuatu ke dalam jiwa penonton dan terimplementasi melalui perilaku mereka. Kelima, agenda setting theory, merupakan pengaturan informasi yang ingin disampaikan media. Keenam, technological determinism theory yaitu tentang perubahan berbagi macam komunikasi akan membentuk pula keberadaan manusia. Untuk mempermudah penjelasan, perlu kiranya diberikan skema proses komunikasi politik.

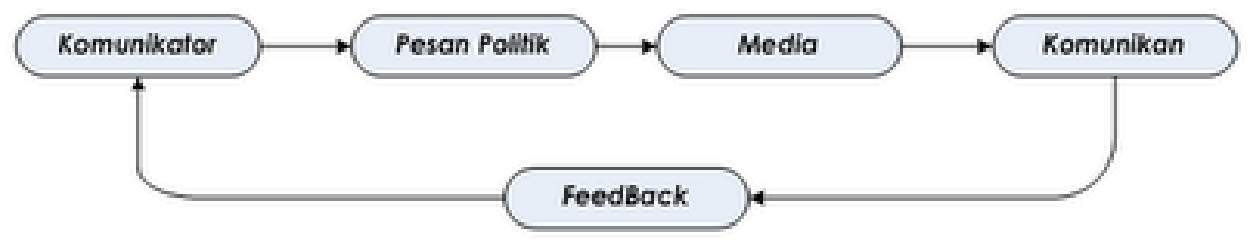

\section{PEMBAHASAN}

\section{Sejarah Puri Ubud}

Menurut beberapa babad dan penelitian, Ubud di Abad XVII masih terdiri dari sawah ladang, semak belukar dan hutan. Sebagiannya sudah didiami penduduk, seperti di Jungut, Taman dan Bantuyung yang merupakan wilayah Kerajaan Sukawati, sekitar tahun 1710. Raja pertamanya bernama Sri Aji Maha Sirikan, Sri Aji Wijaya Tanu. Sedangkan di Desa Peliatan dipimpin Raja I Dewa Agung Made, dua adiknya ditugaskan memegang wilayah, Ida Tjokorda Gde Karang di Desa Padang Tegal dan Ida Tjokorda Tangkeban di Ubud. Banyak pura berdiri dalam masanya. Ketika Ubud makin berkembang, Ida Tjokorda Tangkeban meninggalkan Ubud. Sehingga Ubud tanpa pemimpin. Bandesa Mas di Jungut mengambil inisiatif ke Puri Peliatan, nuhur pemimpin untuk Ubud. Raja Peliatan saat itu memerintahkan Ida Tjokorda Putu Kandel untuk memimpin Ubud. la mendirikan Puri Saren Kangin Ubud. Kemudian, setelah wafat, ia diganti putranya, Ida Tjokorda Putu Sukawati, membangun Puri Saren dan Saren Kauh.

Pada masa kepemimpinannya, Ubud semakin maju. Kegiatan adat dan agama yang semarak di Ubud, telah mendorong 
berkembangnya seni dan budaya. Seni dan tradisi merupakan kesatuan yang tidak terpisahkan antara agama, adat, budaya dan masyarakat.

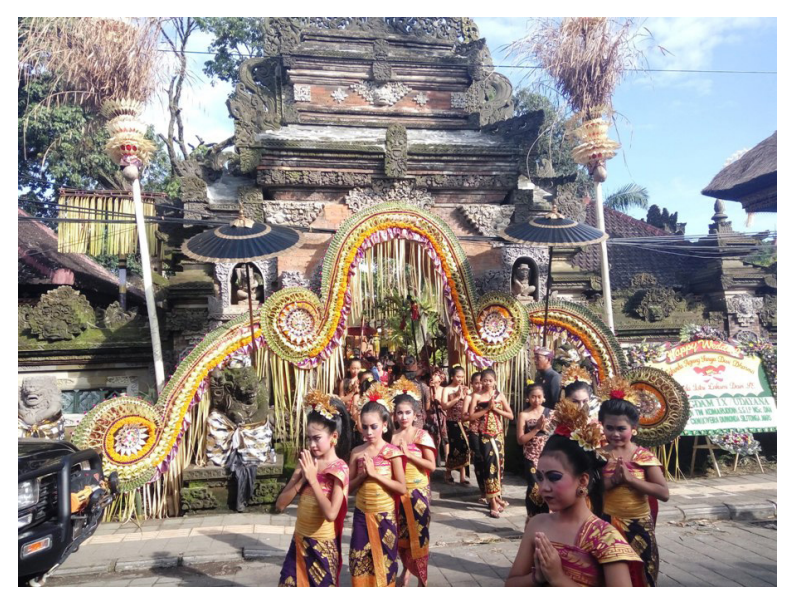

Sumber Dok. Pribadi

Gambar 2. Gapura Barat Puri Ubud

Kepemimpinan selanjutnya diteruskan putra tertua, Tjokorda Rai Batur dari tahun 1850 hingga 1880. Selanjutnya, di tahun 1880-1917 kepemimpinan Puri Ubud dilanjutkan Tjokorda Gde Sukawati. Tahun 1900, Ubud membuat permohonan menjadi wilayah protektorat Belanda. Setelah itu penjajah ikut campur. Setelah Tjokorda Gde Sukawati wafat, ia dilanjutkan putra terkecil, Tjokorda Gde Agung Sukawati atau tokoh yang membuka akses dunia luar. Pada masa itu Belanda sudah masuk, membentuk Pemerintahan di Ubud yang dipimpin oleh perbekel. Namun secara adat kepemimpinan di kalangan keluarga Puri Ubud masih menjalankan tradisi. Jadi Tjokorda Gde Agung Sukawati merupakan raja terakhir Ubud yang dinobatkan tahun 1917. Tjokorda Gde Agung Sukawati (19171978) adalah seorang raja Ubud yang jasanya tak ternilai dalam membangun peradaban madani di Bali. Tjokorda membawa perubahan besar di Ubud Bali. Raja ini hidup dengan visi yang melampau pemikiran orang-orang pada masanya. Status sosial sebagai raja membuatnya dipuja dan ditinggikan rakyat Ubud.

Sejak Belanda menguasai Bali, Puri Ubud tidak lagi memimpin wilayah Ubud dengan sistem kerajaan. Pemerintah
Belanda membentuk pemimpin baru di wilayah Ubud. Era ini menjadi awal era modern di Ubud, sekitar tahun 1930 ketika seniman dengan dukungan keluarga kerajaan, mengadakan pertunjukkan di kota bahkan hingga Eropa. Sekitar tahun 1960, turis mulai berdatangan. Hal tersebut terjadi hingga pendudukan Jepang 1942. Namun secara adat, masyarakat Ubud masih dipimpin keluarga Puri Ubud. Selain itu keluarga besar Puri Ubud patuh struktur aturan kelembagaan puri yang diwariskan leluhurnya. Pada era pergerakan kemerdekaan Puri Ubud merupakan salah satu penentang penjajah Belanda hingga ada seorang tokoh puri Ida Tjokorda Putra Sudarsana meninggal ditembak Belanda. Setelah merdeka Presiden Soekarno beberapa kali ke Puri Ubud menyaksikan karya seniman Ubud.

Selanjutnya, kepemimpinan Puri Ubud dilanjutkan kemenakannya asal Puri Saren Kauh, anak dari saudari kembar perempuannya, Tjokorda Gde Agung Suyasa. Sekitar tahun 1979-2008, ia ditetapkan menjadi pengelingsir puri tanpa dinobatkan seperti pemerintahan kerajaan karena sudah ada perbekel yang memimpin Ubud dan wilayah Ubud bukan kerajaan lagi. Namun, di kalangan keluarga tokoh yang dituakan tetap dihormati seperti raja. Kini keluarga Puri Ubud telah mencapai sekitar 100 Kepala Keluarga, bahkan lebih.

Secara fisik Puri Ubud dibagi menjadi beberapa areal. Yakni, Puri Saren Kangin Baleran yang posisinya berada di sisi timur laut, Puri Saren Kangin Delodan yang posisinya berada di sisi Tenggara, Puri Saren Agung atau Rangki dengan posisi di tengah, Puri Saren Kauh di sisi barat. Sedangkan lainnya telah membangun puri baru di Ubud dan sekitarnya dengan sebutan Ksatria Dalem Sukawati (KDS). Setelah Tjokorda Gde Agung Suyasa wafat (2009), pimpinan Puri Ubud kembali ke Saren Agung atau Rangki dengan menetapkan, Tjokorda Gde Putra Sukawati sebagai kepala keluarga, dikenal dengan Pengelingsir Puri atau tokoh dituakan. Pemerintahan wilayah Ubud senjak dua Pengelingsir Puri tidak 
lagi menggunakan sistem kerajaan. Saat itu Indonesia sudah menjadi Negara Kesatuan Republik Indonesia. Tokoh puri mengambil peran dan pimpinan secara adat saja. Keberadaan keluarga Puri Agung Ubud yang awalnya berada di Puri Agung Ubud kini telah menyebar membangun beberapa puri sebagai tempat tinggal.

\section{Strategi Komunikasi Politik Tokoh Puri Ubud}

Masyarakat Ubud merupakan salah satu sumber daya atau modal untuk menggerakkan pembangunan sekaligus pelestarian tradisi. Namun jika tradisi yang dilaksanakan merugikan maka akan susah dilaksanakan, syukur tradisi tersebut menjadi penunjang pariwisata walaupun diiringi dampak yang kurang sejalan. Tahun 2014 penduduk Ubud sebesar 12.145 jiwa bila dibandingkan dengan luas wilayah yang dimiliki yaitu $7,8 \mathrm{~km}^{2}$, diperoleh tingkat kepadatan penduduk rata-rata pada tahun 2014 sebesar 1.557 jiwa / km². Menurut standard FAO, tingkat kepadatan penduduk di Kelurahan Ubud masuk kategori sangat padat.

Pada saat inilah tokoh puri mulai membangun peran dalam masyarakat seperti tokoh keagamaan, Pengajeg Karya Agung (Ketua Upacara Ritual Besar), Ketua Lembaga Pemberdayaan Masyarakat Kelurahan Ubud, Bendesa Desa Pakraman Ubud atau pimpinan Desa Adat Ubud dan organisasi lain. Beberapa tokoh puri juga menjabat di pemerintahan, pengusaha, serta berhasil membangun pelbagai fasilitas masyarakat. Sebelumnya seorang Tokoh Puri Ubud yaitu, Alm DR. Ir. Tjokorda Raka Sukawati asal Puri Sosrobahu Ubud memberikan andil berharga bagi bangsa dan negara, khususnya pembangunan fisik. la menciptakan teknik pembangunan yang dipatenkan dengan nama "Sosrobahu", teknik ini merupakan teknologi pembangunan jalan layang yang disebut teknik putaran bebas hambatan yang diciptakan dalam pembuatan jalan layang di Jakarta dan dalam pembangunan jalan layang di seluruh dunia.

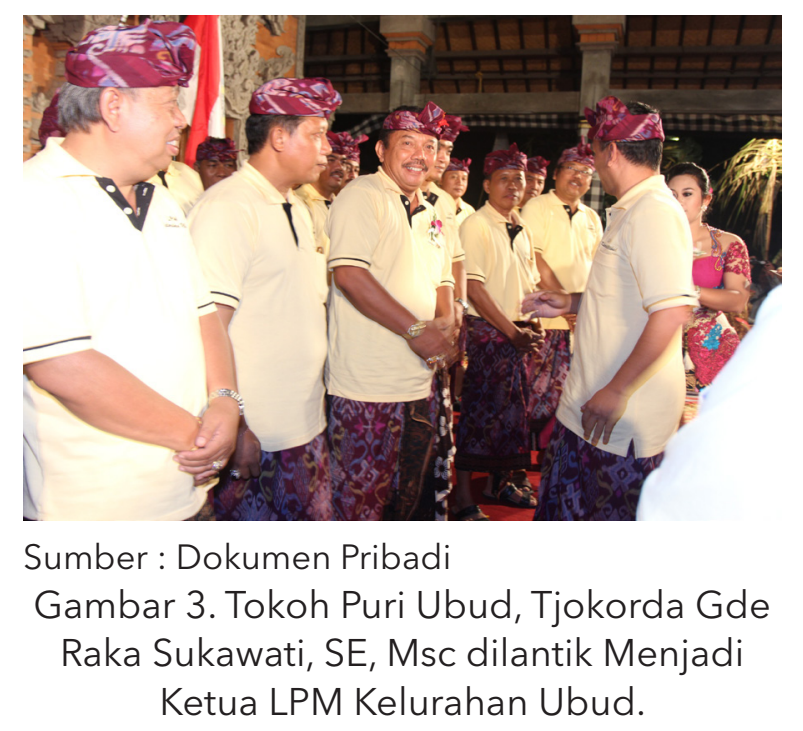

Pada masa pemerintahan RIS, Tjokorda Raka Sukawati yang pernah menjadi anggota Volksraad selanjutnya diangkat menjadi Presiden Negara Indonesia Timur (NIT) bagian dari Republik Indonesia Serikat (RIS). Peran itu bermanfaat bagi tokoh puri dalam memantapkan pondasi politik. Dalam konsep Bourdieu dalam Fashri (2007 :95), ranah merupakan arena kekuatan yang didalamnya terdapat upaya perjuangan untuk memperebutkan sumber daya dan juga demi memperoleh akses tertentu yang dekat dengan hirarki kekuasaan. Puri Ubud beserta tokoh didalamnya adalah anggota yang aktif menjalin hubungan sosial dengan warga, disamping itu Puri Ubud juga sukses dalam pelestarian budaya yang bermuara pada peningkatan empat modal Puri Ubud. Situasi tersebut dikuatkan pendapat Pierre Bourdieu yang menyatakan ada empat jenis modal untuk menjalin komunikasi politik. Empat modal tersebut adalah, modal ekonomi, modal sosial, modal budaya dan modal simbolik, Fashri dalam Wilasa (2011: 131).

\section{Modal Ekonomi}

Puri Ubud merupakan salah satu puri di Gianyar yang dikenal memiliki kemampuan ekonomi mapan, terutama terhadap kepemilikan sawah, tegalan hingga aset pariwisata. Sarana ini merupakan modal tokoh puri untuk tetap dikenal dan memiliki pengakuan di masyarakat atau politik. Modal ekonomi sudah dirintis sejak leluhur 
Puri Ubud, dan dikembangkan sesuai situasi kekinian. Puri Ubud juga membuka akses untuk berbagai kegiatan kesenian.

Tokoh Puri Ubud juga memiliki usaha dibidang pariwisata, disamping itu secara akumulatif keluarga Puri Saren Ubud termasuk daftar orang terkaya di Bali. Usaha di bidang pariwisata juga dimiliki sebagian anggota keluarga besar puri lain, berupa hotel, restoran, penginapan dan lainnya. Modal ekonomi ini menjadikan Puri Ubud dikenal warga secara ekonomi dan berdampak terhadap pelestarian tradisi.

\section{Modal Sosial}

Modal Sosial menunjuk pada jaringan sosial yang dimiliki pelaku (individu atau kelompok) terkait hubungannya dengan pihak lain yang memiliki kuasa, Bourdieu dalam Fashri (2007:99). Kaitan dengan penelitian ini Modal Sosial adalah jaringan sosial dalam berbagai komunitas masyarakat yang dimiliki pihak keluarga Puri Ubud. Jaringan ini diperkuat dengan sarana komunikasi yang canggih, media sosial ataupun dunia digital secara tidak langsung mampu meningkatkan popolaritas Puri Ubud.

Keluarga Puri Ubud dikenal dermawan dalam menyumbangkan harta dan pikiran dalam pelbagai kegiatan pembangunan pura. Alm Tjokorda Gde Agung Suyasa tidak hanya dikenal di Ubud atau Bali, bahkan dikenal hingga ke Jawa, Kalimantan, Tambora, Lombok dan pura lain di Indonesia. Keluarga puri dikenal karena selalu menjadi barisan teratas dalam membangun pura. Jika ada warga memohon bantuan, tidak segan keluarga puri membantu warga. Bantuan bukan saja pemikiran tetapi juga harta. Pura yang berhasil dibangun yakni, Pura Mandhara Giri Semeru Agung di Kecamatan Senduro, Kabupaten Lumajang, Jawa Timur, Pura di Kutai Kartanegara Kalimantan Timur, Pura Rinjani di Lombok, Pura Tambora di Nusa Tenggara dan lainnya.

Di Bali, tokoh Puri Ubud dipercaya menjadi Pengrajeg Karya. Modal ini secara tidak langsung meningkatkan eksistensi Puri Ubud. Apalagi saat ritual Mendem
Pedagingan, tokoh Puri Ubud selalu menyumbangkan sarana dasar sebagai modal atau investasi kepada Tuhan di pura tersebut. Sehingga warga pemilik pura selalu mengingat jasa Puri Ubud. Dalam meningkatkan srada bakti pada Tuhan, tokoh Puri Ubud juga dikenal ahli dalam membuat Barong atau topeng. Ini merupakan benda sakral. 'Barong atau Topeng terbuat dari Kayu disebut kayun atau pikiran yang tulus, sedangkan Barong dikaitkan dengan bareng yang artinya bersama-sama, jika sesuatu dilaksanakan dengan pikiranbersih dan suci dan dilaksanakan bersama akan menghasilkan kebaikan bersama'. (wawancara Tjokorda Raka Kerthyasa, 21 Januari 2018).

Francis Fukuyama menyebut modal sosial berupa jaringan sosial masih kental di era sekarang. Kemampuan membangun jaringan sosial dan kemampuan mengabdi kepada rakyat (modal sosial) masih kental di Puri Ubud. Melalui proses yang sophisticated ini, puri kembali mengambil kekuasaan zaman dulu yang sudah lama hilang.

Modal kepemimpinan tidak hanya kekayaan (berupa tanah), kekuasaan, tetapi juga kultural, Giddens dalam Suryadi (2007:14). Kepatuhan masyarakat sering mengacu pada individu dengan kelebihan gaib atau kualitas personal yang lebih dibandingkan orang lain. Hal itu dikuatkan oleh tokoh Puri Saren Kauh Ubud, "Tiang selalu menjalankan kewajiban selaku warga puri yang mengayomi dan berbagi dengan warga, ini tugas sejak leluhur, warga yang memohon bantuan tidak boleh kecewa karena mempercayakan tugas kepada tiang" (wawancara dengan Tjokorda Raka Kerthyasa, 5 Januari 2018). Elit Puri juga dipercaya memimpin event internasional seperti Ubud Festival dan Ubud Writers Readers Festival. 


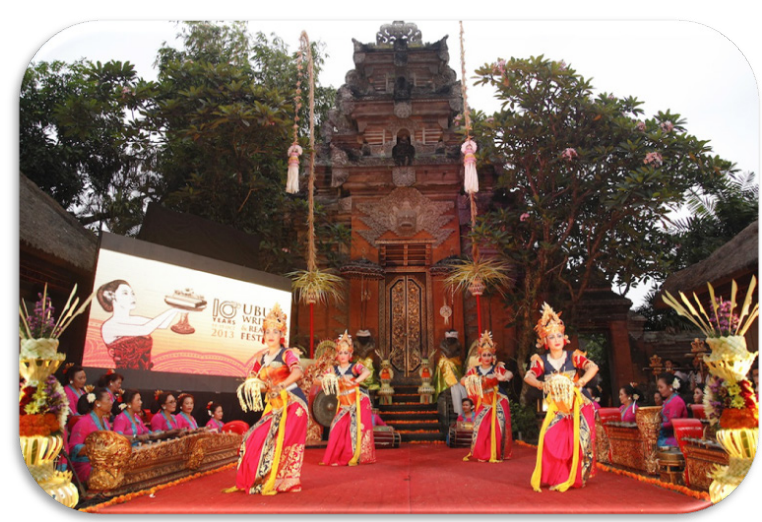

Sumber :Dokumentasi Puri Ubud

Gambar 4. Ancak Saji Puri Agung Ubud Sebagai Media Pelaksanaan Ubud Writers Readers

\section{Modal Budaya}

Modal Budaya bukan saja diwariskan leluhur selaku pemegang Tahta Puri Ubud, modal budaya merupakan warisan adiluhung. Modal inilah yang membuat kejayaan Puri Ubud dikenal, bukan saja akibat kekayaan yang dimiliki. Kebesaran nama Puri Ubud juga karena pendidikan. Keluarga puriselalu mengenyam pendidikan tingkat tinggi bahkan sampai ke luar negeri. Pendidikan lain yang tidak secara formal juga diraih keluarga Puri Ubud, mereka tidak segan belajar ke orang lain, seperti pendeta atau tokoh masyarakat tertentu. Keluarga puri juga memiliki perpustakaan berupa tulisan lontar sebagai acuan pelaksanaan tradisi dan ritual.

Beberapa puri di Bali juga mengembangkan bisnis pariwisata, yang bermuara pada usaha membangun citra puri. Graeme MacRae (2004), Citra puri dibentuk lewat hal lebih halus seperti membantu perbaikan pura, desa adat, dan upacara keagamaan lain. Jika ada kegiatan, masyarakat datang untuk ngayah atau membantu tanpa diberitahu. Pada saat upacara Pelebon Agung atau upacara pembakaran mayat bagi keluarga puri, kegiatan ini meningkatkan karakter dan tradisi Ubud. Pihak Puri Ubud selalu membuat penghormatan khusus terhadap yang sudah meninggal. Itu akan meningkatkan kualitas kelahiran kembali dan memberikan jalan terbaik mendiang. Dalam berbagai kegiatan Pelebon, pihak
Puri Ubud selalu membuat Bade atau alat pengusungan jenasah dengan bentuk Bade yang tingginya mencapai 25 meter dengan berat 10 ton. Bahkan saat upacara Pelebon terakhir yang dihadiri ribuan warga hingga tokoh nasional, tokoh Puri Saren Agung, Tjokorda Gde Raka Sukawati raih rekor MURI untuk pembuatan Bade tertinggi.

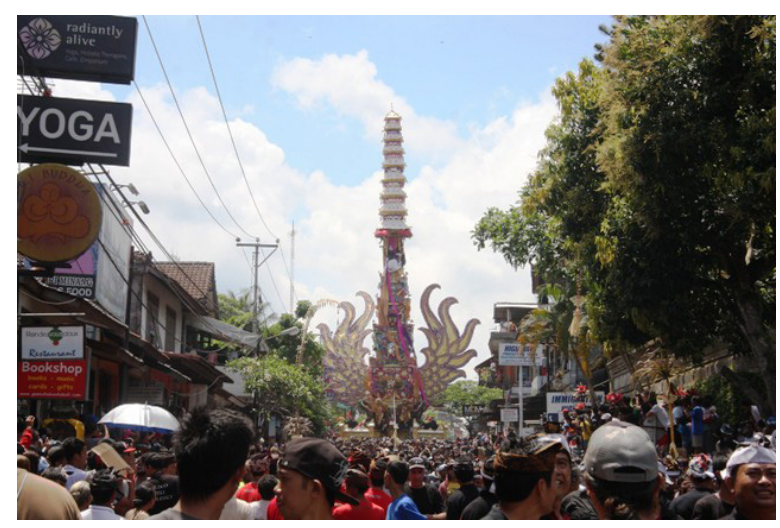

Sumber :Dokumen Pribadi

Gambar 5. Pelebon Keluarga Puri Ubud Menggunakan Bade dan diusung Ribuan warga

Upacara seperti ini dijadikan modal dalam mengenalkan tradisi dan Puri Ubud kepada kalangan masyarakat. Apalagi ritual dimuat dalam beberapa media cetak nasional ataupun elektronik, internet juga ikut menyebarkan informasi pelaksanaan Pelebon oleh masyarakat pengguna internet di media sosial. Menurut Geriya (2016-48) menyebutkan, Ubud merupakan daerah seni pertunjukan dan seni rupa. Walaupun seni lainnya juga dominan. Wisatawan yang datang ke ubud umumnya ingin menyaksikan pertunjukan dan seni rupa hasil seniman Ubud. Dari data kunjungan wisatawan ke Kabupaten Gianyar tersebut 70 hingga $80 \%$ wisatawan berkunjung ke Ubud.

\section{Modal Simbolik}

Modal Simbolik, menjadi anggota keluarga Puri Ubud diyakini beberapa masyarakat sebagai keturunan raja. Di beberapa warga masyarakat masih meyakini akan keturunan raja atau puri bukan berasal dari masyarakat biasa, mereka memiliki kelas khusus dan dikaitkan dengan 
keturunan dewa. Disamping itu jasa tokoh puri juga menjadi salah satu tolok ukur masyarakat dalam memposisikan keluarga dan Puri Ubud sebagai kelas khusus. Hal ini dibuktikan dari beberapa catatan sejarah yang dilakukan seperti, Tjokorda Gde Agung Sukawati dan keluarga Puri Ubud lainnya yang jasanya tak ternilai dalam membangun peradaban madani di Bali.

Tjokorda Gde Agung Sukawati membawa sebuah perubahan besar di Ubud Bali. Keluarga Puri Ubud ini selalu hidup dengan visi melampaui pemikiran orang pada masanya. Status sosial membuatnya ditinggikan rakyat Ubud. Pada tahun 2016, Bupati Gianyar memberikan penghargaan kepada Tjokorda Gde Agung Sukawati dan Tjokorda Gde Raka Sukawati yang berjasa di bidang pariwisata dan kebudayaan Ubud dengan penganugerahan Parama Bakti Pariwisata.. Pada masyarakat Ubud, tokoh puri dihormati dengan hak khusus. Penguasaan jabatan seperti itu sebagaimana jaman kerajaan masih didominasi keluarga Puri Ubud. Sedangkan jabatan lain di pemerintahan juga didominasi keluarga puri, seperti Ketua LPM Ubud, Bendesa Pakraman Ubud hingga pimpinan organisasi formal ataupun non-formal. Kebiasaan yang dibudayakan oleh pihak Puri Ubud merupakan bagian yang tidak dipisahkan dari masa lalu atau sejarah. Fashri (2007:91) dalam Wilasa (2012:146).

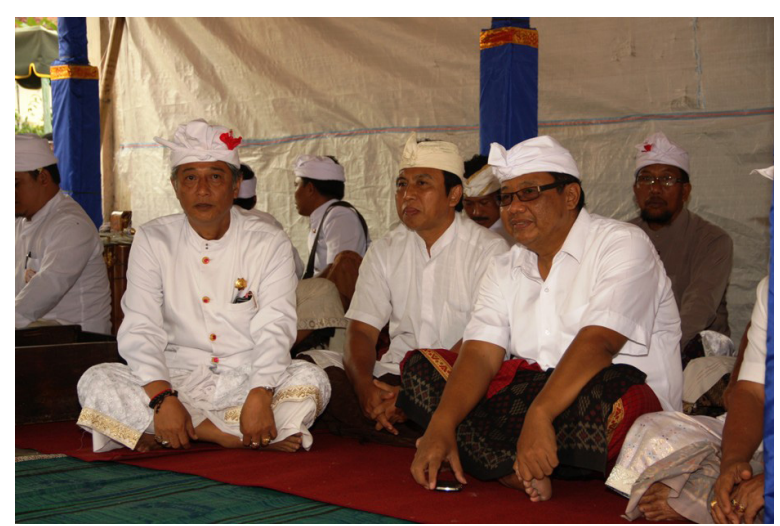

Sumber : Dokumen Pribadi

Gambar 6. Mentri Koprasi AA Puspayoga diterima Tjokorda Raka Kerthyasa Saat Memimpin Upacara Keagamaan
Jabatan yang hingga kini masih dipegang keluarga Puri Ubud, seperti pimpinan masyarakat Adat Ubud atau Bendesa Desa Pakraman Ubud masih dipegang Tjokorda Raka Kerthyasa, Ketua Lembaga Pemberdayaan Masyarakat Ubud dipegang Tjokorda Gde Raka Sukawati asal Puri Saren Agung, Ketua PHRI Bali masih dipegang Tjokorda Oka Artha Ardhana Sukawati, tokoh puri lain juga dipercaya menjadi Ketua Komite di beberapa sekolah di Ubud, seperti Ketua Komite SMPN 1 Ubud, SMAN 1 Ubud dan beberapa sekolah swasta lainnya.

Pelbagai jenis jabatan tersebut semakin menguatkan pesan bahwa keluarga puri memiliki otoritas dan legitimasi tertentu di masyarakat. "Prestise seperti itu kami peroleh tiada lain karena melakoni tugas dan tanggung jawab yang diwariskan leluhur, masyarakat juga masih mempercayakan keluarga puri untuk mengemban berbagai tugas, sedangkan kami di puri tidak akan pernah berharap balasan, karena itu merupakan kewajiban yang diamanatkan leluhur kami" (wawancara dengan Tjokorda Oka Artha Ardana Sukawati, 05/01/2018).

Pernyataan mohon dukungan dalam politik tidak disampaikan secara vulgar sehingga tokoh asal Puri Ubud di Kabupaten Gianyar berkali-kali menjadi Bupati Gianyar, anggota DPRD dan menduduki jabatan di partai politik. Sesungguhnya komunikasi politik tokoh Puri Ubud dilaksanakan secara terus menerus, namun tidak dinyatakan secara nyata. Mereka mengesampingkan politik saat mengabdi tentang urusan agama, adat ataupun tradisi. Modal tersebut diaktualisasikan melalui media Bali TV dan beberapa radio swasta maupun radio komunitas. Puri Ubud memiliki tim khusus yang bertugas menjalankan media relations.

\section{E. KESIMPULAN}

Berdasarkan deskripsi sebelumnya dapat ditarik kesimpulan terhadap keseluruhan penelitian ini. Pertama, secara keseluruhan komunikasi politik Puri Ubud telah dilaksanakan jauh sebelum negara Indonesia menjadi negara demokrasi. 
Komunikasi ini dijalin kalangan Puri Ubud sejak zaman kerajaan. Saat era perjuangan kemerdekaan, beberapa tokoh Puri Ubud juga masih memiliki prestise dan sudah menduduki jabatan penting hingga salah tokoh puri berhasil menjadi Presiden Negara Indonesia Timur di era pembentukan Republik Indonesia Serikat. Setelah jaman kemerdekaan, beberapa tokoh pejuang asal Puri Ubud juga memiliki hubungan dekat dengan pemerintah, sehingga beberapa kali Presiden Soekarno berkunjung ke Puri Ubud.

Pasca Indonesia menjadi Negara kesatuan Republik Indonesia, Puri Ubud tidak lagi menobatkan salah satu keturunan mereka menjadi raja, karena perubahan sistem pemerintahan dari kerajaan ke sistem replublik. Namun, disisi adat, agama, budaya dan tradisi keluarga Puri Ubud masih terlibat dalam pelaksanaan dan sering dijadikan pemimpin ritual keagamaan.

Ketekunan melaksanakan tatanan agama, adat, budaya dan tradisi menyedot perhatian wisatawan untuk datang ke Ubud. Sehingga perkembangan pariwisata di Ubud semakin dikenal dan menjadi salah satu destinasi wisata terbaik dunia. Dampak dari kemajuan pariwisata budaya tersebut membuat keluarga Puri Ubud mengembangkan eksistensinya, selain modal sosial dan simbolik, modal budaya dan ekonomi mulai berkembang di kalangan keluarga Puri Ubud.

Perkembangan empat modal ini secara langsung bedampak terhadap eksistensi Puri Ubud. Perkembangan tersebut secara otomastis meningkatkan jaringan dan modal sosial Puri Ubud. Semakin banyak masyarakat yang dibantu dan memohon bantuan ke Puri Ubud membuat tokoh Puri Ubud semakin mudah menyebarkan dan memberikan pengetahuan terkait tatanan tradisi.

Kedua, perkembangan pariwisata budaya yang dikembangkan tokoh Puri Ubud sangat berdampak bukan saja untuk masyarakat melainkan bagi Gianyar dan masyarakat Bali. Secara otomatis eksistensi Puri Ubud di mata masyarakat semakin meningkat, apalagi tokoh Puri Ubud mampu menyebarkan informasi tentang tradisi dan kegiatan puri bukan saja lewat komunikasi personal, kelompok atau publik, mereka sudah mampu memanfaatkan media komunikasi massa dan internet. Dari itu mereka berhasil membangun opini masyarakat terkait pentingnya tradisi dalam meningkatkan ekonomi dan pariwisata yang sebagai penyumbang devisa terbesar Bali.

\section{DAFTAR PUSTAKA}

Agger, Ben. 2008. Teori Sosial Kritis(Terjemahan) Yogyakarta : Kreasi Wacana.

Anonimus. 2006. Undang-Undang Nomor 32 Tahun 2004 tentang Pemerintahan Daerah. Semarang : Dahara Prize.

Arcana, Fajar. 2007. Surat Merah Untuk Bali. Jakarta : Galangpress (Anggota IKAPI).

Artha, I Gusti Putu. 2006. Wacana Berita Surat Kabar Kampanye Pemilihan Kepala Daerah Kabupaten Badung Provinsi Bali Tahun 2005 : Sebuah Kajian Budaya. Tesis Program Program Studi Kajian Budaya Program Pasca Sarjana Universitas Udayana.

Atmaja, Bawa dan Anantawikrama Tungga Atmadja.2009. "Pelampiasan Syahwat Kekuasaan dan "Ngutang Gae, Ngalih Gae": Pemaknaan Pesta Demokrasi di Bali". Dalam Jurnal Kajian Budaya, Kajian Budaya Universitas Udayana, Volume 6 Nomor 11 Januari 2009. Halaman 45-82.

Bagong Suyanto dan Sutinah. 2005. Metode Pemelitian Sosial : Berbagai Alternatif Pendekatan, Jakarta, Prenada Media

Budiardjo, Miriam. 2008. Dasar-dasar Ilmu Politik. Jakarta : PT Gramedia Pustaka Utama. 
Bungi, Burhan. 2005. Metodelogi Penelitian Kualitatif. Cetakan Pertama. Jakarta : Prenada Media

Cangara, H. 2009. Komunikasi Politik: Konsep, Teori, dan Strategi. Raja Grafindo. Jakarta.

Cangara, H. 2005. Pengantar Ilmu Komunikasi. Raja grafindo Persada. Jakarta

Dedi, Aji Mulawarman. 2007. "Perubahan Dengan Eksistensi Habitus". Dalam ajidedim. wordpress.com. 12/26/2007.

Dinas Kebudayaan Kabupaten Gianyar (2018). Memori Pengabdian Bupati Gianyar AA Gde Agung Bharata. DEVA Communications.

Dwipayana, Ari. 2006. Pergulatan Politik Representasi atas Bali. Denpasar: Uluangkep Press.

Effendy, Onong Uchjahna. 1992. Dinamika komunikasi. Pt Remaja Rosda Karya. Bandung.

Effendy, Onong Uchjahna. 1990. Ilmu Komunikasi Teori dan Praktek. PT. Remaja Rosda Karya. Bandung

Eriyanto, 2001, Analisis Wacana : Pengantar Analisi Teks Media, LKiS, Yogyakarta.

Fashri, Fauzi.2007. Penyingkapan Kuasa Simbol. Yogyakarta : JUXTAPOSE.

Firmanzah. 2007. Marketing Politik. Jakarta: Yayasan Obor Indonesia.

Geriya, W. 1995. Pola Partisipasi dan Pemberdayaan Sumber Desa Adat dalam Perkembangan Pariwisata. Denpasar. Upada Sastra

Hamad, Ibnu. 2004, Konstruksi Realitas Politik Dalam Media Massa : Sebuah Study Critical Discourse Analysis Terhadap Berita-berita Politik, Granit, Jakarta.

Haryanto. 2005. Kekuasaan Elit. Yojakarta: Program Pascasarjana (S2) Universitas Gadjah Mada.

I Putu Gede Suwitha, Jurnal Kajian Bali, Elite Puri dalam Lanskap Politik Kontemporer di Bali. Volume 05, Nomor 01, April 2015

Ishwara, Luwi. 2005. Catatan-catatan Jurnalisme Dasar. Cetakan Pertama. Jakarta : Penerbit Buku Kompas.

Jondra, I Wayan dan I Nengah Sujaya (ed). 2007. Kepemimpinan yang Balinese. Denpasar: PT. Empat Warna Komunikasi.

Khairul Muluk, Mujibur Rahman. 2007. Menggugat Partisipasi Publik Dalam Pemerintahan Daerah; Sebuah Kajian dengan Pendekatan Berpikir Sistem. Malang: Banyumedia Publishing.

McQuail, Dennis. 1987. Mass Communication Theory, An Introduction (2 $\left.{ }^{\text {nd }}\right)$. Newbury Parks Sage

Mulyana, Dedy. 2000. Ilmu Komunikasi Suatu Pengantar. Pt Remaja Rosda Karya. Bandung.

Mulyana. 2005. Kajian Wacana. Teori, Metode dan Aplikasi Prinsip-prinsip Analisis Wacana. Cetakan Pertama. Yogyakarta : Tiara Wacana.

Mu'ti, Abdul.2009. Demokrasi Feodal. Dalam www.unisosdem.org, 3 Maret 2009.

Mufid, Muhamad, 2007, Komunikasi \& Regulasi Penyiaran, Kecana, Jakarta.

Mulyana, Deddy , 2004, Metode Penelitian Kualitatif Paradigma Baru Ilmu Komunikasi dan Ilmu Sosial lainnya, hal 106, Remaja Rosdakarya Bandung.

Nazir, Moh. 1998. Metode Penelitian. Cetakan Ketiga. Jakarta : Ghalia.

Nurudin. 2007. Pengantar Komunikasi Massa. Raja Grafindo Persada. Jakarta. 
Panuju, Redi. 2002. Krisis Public Relations. Yogyakarta: Pustaka Pelajar

Panuju, Redi. 2017. Sistem Penyiaran Indonesia. Jakarta: Prenada Mediagroup

Panuju, Redi. 2017. Konvergensi Media Dakwah: Studi Kasus Radio Komunitas Ma'dinul Ulum Tulungagung. Jurnal Komunikasi Islam Volume 07 (1), Juni 2017: 88-106. ISSN: 2088-6314

Pareno, Sam Abede. 2005. Media Massa antara Reulitas dan Mimpi. Cetakan Pertama. Surabaya : Papyrus.

Pasaribu, Rondang. 1999. "Pers dalam Tatanan Politik yang Berubah". Dalam Menuju Masyarakat Kewargaaan, Afnan Malay dkk (editor). Cetakan Pertama, Yogyakarta : LP3Y.

Piliang, Yasraf Amir. 2004. Posrealitas, Realitas Kebudayaan Dalam Era Postmetafisika. Cetakan Pertama. Yogyakarta : Jalasutra.

Piliang, Yasraf Amir., 2005, Tanspolitika, Dinamika Politik dalam Era Vitualitas. Cetakan Pertama. Yogyakarta : Jalasutra.

Poerwardarminta. 2003. Kamus Umum Bahasa Indonesia. Cetakan Ketiga. Jakarta : Balai Pustaka.

Pujiastuti. 2014. Kompetensi Komunikasi Antar Budaya : studi Etnografi Komunikasi Antar Budaya di Asrama Mahasiswa ITS Surabaya. Tesis Program Program Studi Ilmu Komunikasi Universitas Dr Soetomo Surabaya.

Rivers, William L dkk. 2003. Media Massa dan Masyarakat Modern. Cetakan Pertama. Jakarta: Kencana.

Romli, Lili. 2005. "Pilkada Langsung, Otonomi Daerah dan Demokrasi Lokal", Dalam Jurnal Analisis CSIS, Volume 34 Nomor 3 September 2005, Halaman 279-290.

Ruslan, Rosady. SH.MM. 2008. Manajemen Pulic Relations dan Media Komunikasi, Rajawali Pers. Jakarta

Sastrodiwiryo, Dr Soegianto. Perjalanan Dang Hyang Nirartha Sebuah Dharmayatra (14791560)Dari daha Sampai Tambora. Pt BP. Denpasar.

Senjaya, Sasa Djuarsa. 1993. Pengantar Komunikasi, Universitas Terbuka, Jakarta

Siebert, Fred. S. 1986, Empat Teori Pers (terjemahan oleh Putu L.S. Pendit), Jakarta: PT Intermasa.

Sobur, Alex. 2004. Semiotika Komunikasi. Cetakan Kedua. Bandung : Rosda Karya

Soebandi, Jro Mangku Gde Ketut. Mengenal leluhur Dari Dunia Babad. Denpasar. Pustaka Bali Post.

Sudiana. 1986. Komunikasi Periklanan Cetak. Bandung: Remadja Kary.

Sudibyo Agus, 2006, Politik Media dan Petarungan Wacana, Cetakan Kedua. LKIS Yogyakarta.

Sugiyono, Pof. Dr. 2009. Metode Penelitian kuantitatif, Kualitatif dan R \& D, CV Alfabeta, Bandung

Suharno dan Ana Retnoningsih. 2005. Kamus Besar Bahasa Indonesia (KBBI). Semarang: CV Widya Karya.

Sukawati, Tjokorda Oka A.A, (ed). 2006. Kembang Rampai Desa Ubud. Denpasar: Pustaka Nayottama.

Surpa, I Wayan. 2005. Pengantar Hukum Hindu. Surabaya. PARAMITA. 
Suprayogo, Imam dan Tobrini. 2001. Metodelogi Penelitian Sosial-Agama. Cetakan Pertama. Bandung : Rosda.

Suryadi, Budi. 2007. Sosiologi Politik.IRCiSod. Djogjakarta.

Suyasa, Tjok Gde Agung. 2005. Babad Dalem Sukawati.

Rosady Ruslan. 1998. Manajemen Publik Relation dan Media Komunikasi. Jakarta, Pt Raja Grafindo Persada.

Tester, Keith. 2003. Media, Budaya, dan Moralitas. Cetakan Pertama. Yogyakarta : Juxtapose dan Kreasi Wacana.

Wattimena, Reza A.A.2009. (essai) Feodalisme Sebagai Musuh Demokrasi.' Dalam Kompas : 30 April 2009.

Werner J Severin dan James W. Tankard, Jr. 2001. Teori Komunikasi : Sejarah,Metode, dan Terapan di dalam Media Massa. Prenada Media. Jakarta.

Widodo. 1997. Teknik Wartawan Menulis Berita di Surat Kabar dan Majalah. Cetakan Pertama. Surabaya : Penerbit Indah

Wilasa, Nyoman. 2012. Relasi Kekuasaan Puri Ubud Dengan Partai Politik Pada Pilkada 2008 Kabupaten Gianyar Propinsi Bali : Sebuah Kajian Budaya. Tesis Program Program Studi Kajian Budaya Program Pasca Sarjana Universitas Udayana. 